\title{
Perceived Sources and Levels of Stress Among Turkish Dental Students: A Multi-centre Study
}

\section{Türk Diş Hekimliği Öğrencileri Arasında Algılanan Stres Kaynakları ve Düzeyleri: Çok Merkezli Bir Çalışma}

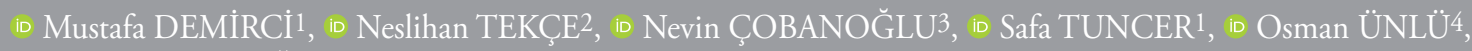

(i) Soner ŞIŞMANOĞLU5 ${ }^{5}$, id Canan BAYDEMIR ${ }^{6}$

1'stanbul University Faculty of Dentistry, Department of Restorative Dentistry, İstanbul, Turkey

2Kocaeli University Faculty of Dentistry, Department of Restorative Dentistry, Kocaeli, Turkey

${ }^{3}$ Selçuk University Faculty of Dentistry, Department of Restorative Dentistry, Konya, Turkey

${ }^{4}$ İstanbul University Faculty of Dentistry, Department of Endodontics, İstanbul, Turkey

${ }^{5}$ Altınbaş University Faculty of Dentistry, Department of Restorative Dentistry, İstanbul, Turkey

${ }^{6}$ Kocaeli University Faculty of Dentistry, Department of Biostatistics and Medical Informatics, Kocaeli, Turkey

\section{ABSTRACT}

Objective: The objective of this study is to examine the perceived sources and levels of stress reported by three different dental faculty students from Turkey. This study also aims to compare stress sources among these students with respect to the role of faculties, specific curricula and institutional differences.

Methods: In total, 1,294 students participated in a survey in 2015. This survey used Modified Dental Environmental Stress questionnaire comprising 47 items that were grouped into 6 categories: academic performance; preclinical and clinical training; patient treatment; faculty administration and education staff; personal life issues; and professional identity after graduation. Responses were recorded on a four-point rating scale ranging from not stressful (1 point) to very stressful (4 points).

Results: The response rate of the study was $63.3 \%(1,294 / 2,045)$. The "concern about failing the course or year due to the inability to finish clinical schoolwork" (clinical score) was found as the highest stress item (mean score $=3.57$ ). More than one-third of questionnaire items showed the presence of moderate-to-severe stress with mean scores between 3.57 and 3.06. The preclinical and clinical training category showed the highest mean stress score (3.09) than other
ÖZ

Amaç: Bu çalışmanın amacı Türkiye'de üç farklı diş hekimliği fakültesi öğrencilerinin rapor ettikleri algılanan stres kaynakları ve düzeylerini incelemektir. Ayrıca, ögrenciler arasındaki stres kaynaklarını fakülteler, belirli müfredat ve kurumsal farklılıkların rolü açısından karşılaştırmak amaçlanmıştır.

Yöntemler: Çalışmaya üç diş hekimliği fakültesinden toplam 1.294 öğrenci katılmıştır. Kırk yedi maddeli Modifiye Dental Çevresel Stres anketi kullanılmış ve altı kategoriye ayrılmıştır: akademik performans; klinik öncesi ve klinik eğitim; hasta tedavisi; fakülte yönetimi ve eğitim personeli; kişisel yaşam sorunları; ve mezuniyet sonrası mesleki kimlik. Yanıtlar, stresli olmayan (1 puan) çok stresli (4 puan) olarak dörtlü puan sistemine göre kayıt edilmiştir.

Bulgular: Çalışmanın yanıt oranı \%63,3’ür (1.294/2.045). Klinik okul çalışmasının bitirilememesi (klinik puan) nedeniyle dersi veya yılı geçememe korkusu en yüksek stres öğesi (ortalama puan $=3,57$ ) olarak bulunmuştur. Anket sorularının üçte birinden fazlası, ortalama puanları 3,57 ile 3,06 arasında olan orta-şiddetli stres göstermiştir. Klinik öncesi ve klinik eğitim kategorisi diğer kategorilere göre en yüksek ortalama stres skorunu $(3,09)$ göstermiştir. Stres maddelerinin çoğunda ve altı stres kategorisinde,
Address for Correspondence: Mustafa DEMiRCi, İstanbul University Faculty of Dentistry, Department of Restorative Dentistry, İstanbul, Turkey

E-mail: md.demirci@gmail.com ORCID ID: orcid.org/0000-0002-9297-6945

Cite this article as: Demirci M, Tekçe N, Çobanoğlu N, Tuncer S, Ünlü O, Şişmanoğlu S, Baydemir C. Perceived Sources and Levels of Stress Among Turkish Dental Students: A Multi-centre Study. Bezmialem Science 2021;9(3):271-82.

${ }^{\circledR}$ Copyright 2021 by the Bezmiâlem Vakıf University

Bezmiâlem Science published by Galenos Publishing House.
Received: 09.04.2020

Accepted: 01.06.2020 
categories. In most of the stress items and six stress categories, females showed significantly more stress than males. A significant difference was found among at least two or more faculties for each stress category.

Conclusion: The modification of curricula, establishment of student counselling, assignment of student advisors and studentoriented programmes may be considered as stress reduction methods. However, further studies are warranted to examine the success of these methods.

Keywords: Dental education, dental students, stress, stress factors, Turkey kadınlar erkeklerden daha fazla stres göstermiştir. Her stres kategorisi için en az iki veya daha fazla fakülte arasında anlamlı bir fark bulunmuştur.

Sonuç: Müfredatların değiştirilmesi, öğrenci danışmanlığının oluşturulması, öğrenci danışmanlarının atanması ve öğrenci odaklı programlar stres azaltma yöntemleri olarak düşünülebilir. Ancak, bu yöntemlerin başarısını incelemek için daha fazla çalışma yapılması gerekmektedir.

Anahtar Sözcükler: Diş hekimliği eğitimi, diş hekimliği öğrencileri, stres, stres faktörleri, Türkiye

\section{Introduction}

In simple terms, stress is the amount of strain caused by a task that might be perceived positively or negatively and can be adaptive or debilitating. Stress, which is a negative response to anxiety, is yet the sole aspect of stress that has been assessed regarding academic achievement among dental students. Anxiety has been shown to predict reduced performance (1). Largely because of the exhausting nature of the training, dental students frequently feel a great deal of stress during this period (2). The primary causes of stress include academic-based course work and exams, clinical care and personal and faculty-associated factors. The main outcomes of stress were reported to affect academic achievement, psycho-emotional well-being and physical health, which are displayed through behaviours including smoking and alcohol consumption (2).

A few studies have compared stress levels among different faculties, each using alternative teaching styles in line with their respective cultures (3). A study reported the presence of great disparity in how students' perceived stressors, depending on their institution. This disparity was associated with personal and education-related factors (4). In a cross-cultural comparative study of students from Singapore and the United States of America, Yap et al. (5) reported that stressors were principally associated with different areas of their academic courses. Varying degrees of stress appeared to result from course-related factors or the students' immediate surroundings (3). Additionally, differences were reported between the stress levels of preclinical and clinical students; in fact, stressors for the latter were similar, more stress was felt by preclinical students, and sex was again significant (6).

Most stress studies involving dental students used modified versions of the Dental Environmental Stress questionnaire (DES) (7). The 25-item DES questionnaire by Garbee et al. (7) is used to identify the potential areas of stress in dental school education. Stress items are grouped into the following seven stress composite categories of related questions: faculty and administration; academics; manual skills; financial obligations; patient care; personal problems; and family. The mean stress score for each category was calculated by taking the average score of each item in the category. The response to each item is rated from 1 (not stressful) to 4 (very stressful), with a fifth possible response being "not pertinent" $(2,7)$. The DES has been translated into multiple languages and adapted by various cultures, thus making it appropriate for national and international studies $(1,4,6,8-13)$.

Turkey is undergoing a rapid transition from Eastern to Western attitudes, values and lifestyles. The changes increasingly reflect Western values of independence, autonomy and competition $(14,15)$. All these factors and stressors associated with dental environments could affect the stress levels of students. The primary objective of the study is to assess the perceived sources and levels of stress in a large population of Turkish dental students. The study was conducted on students from three different dental faculties in three different cities. Thus, the secondary objective of this study is to establish differences in the sources of stress across diverse dental student populations as well as investigate the impact of specific differences among the institutions.

\section{Methods}

The İstanbul University Faculty of Dentistry Clinical Research Ethics Committee approved the study protocol. Informed verbal consent was provided by each volunteer, and they did not receive any compensation for participation in this study. The Ethics Committee also approved the consent procedure. The entire study was conducted in full accordance with the guidelines of the World Medical Association Declaration of Helsinki.

This study was conducted in three dental faculties located in İstanbul University Faculty of Dentistry) (DF1), Konya Selçuk University Faculty of Dentistry) (DF2) and Kocaeli University Faculty of Dentistry) (DF3). In these three faculties, dental education is taught as a five-year curriculum. The first year focusses on basic science and dental introductory courses. The second year focusses on laboratory and preclinical training dental science courses. In the third, fourth and fifth years, students undergo clinical training. However, some curriculum differences are present among dental faculties. Especially, the difference is about clinical training in the third year. In some courses, students attend clinical training as an observer. In some courses, students participate in clinical training by treating patients. Also, in DF3, students must undergo integrated clinical training in the fifth year. 
All first- to fifth-year dental students were invited to participate in the study from the three dental faculties. In total, 1,294 students in the 2014-2015 academic year enrolled in this study. The questionnaire was administered from April 2015 to June 2015. Questionnaires were given to students when they attended a lecture and a researcher explained the purpose of the survey. Participation was completely voluntary and all responses remained anonymous (16). A total of 15 minutes were allotted for completing the questionnaire. Students were asked not to communicate, talk or comment about the items of questionnaire while filling out the questionnaire (17). The respondents were requested to note their sex at the top of the questionnaire.

Modified versions of the DES compiled by Murphy et al. (10) and Westerman et al. (18) were used as the original templates for our study. The 47 items of the questionnaire used in this study were appropriate for the Turkish dental education system. Previous studies have also used some of these items $(6,10-12,17$ 21). Therefore, the validity and reliability of the questionnaire were not determined. Each response was rated on a Likert-type scale with a four-point rating scale ranging from not stressful (1 point) to very stressful (4 points) $(2,7,10,20)$.

To establish a theoretical framework and clarity in the assessment of the research questions, the 47 items of the questionnaire were grouped into 6 categories $(4,10-12)$. Each category was derived from the factor analyses of DES scales reported in earlier studies $(1,4,7,8,10,12,20,22)$. The categories were as follows: 1$)$ academic performance; 2) preclinical and clinical training; 3) patient treatment; 4) faculty administration and education staff (professors, instructors or clinical supervisors); 5) personal life issues; and 6) professional identity after graduation $(10,13,20)$.

\section{Statistical Analysis}

The statistical software SSPS for Windows version 20.0 was used for statistical analysis (SPSS, IBM Corp., Armonk, NY, USA). Descriptive statistics were used to present the stress scores (mean and standard deviation) for each questionnaire item, six stress categories, and the highest stress item in each category and preclinical and clinical years' stress items of DES (10). The Kolmogorov-Smirnov test was used to test the normality of data distribution. Student's t-test, one-way analysis of variance and Tukey' post hoc test were used to compare the scores for each questionnaire item with respect to sex, academic year and overall scores of all five years. These tests were also used to detect differences among the previously defined parameters.

\section{Results}

\section{Demographic Profile}

Table 1 presents the distribution of students by academic year and sex. A total of 1,294 of 2,045 undergraduate students from the 3 faculties completed the questionnaires with a total response rate of $63.3 \%$. The number of dental students who answered the questionnaires was 554 for the dental faculty in the İstanbul University, 441 for Selçuk University and 299 for Kocaeli University; the response rates were $53.8 \%, 75.1 \%$ and $69.9 \%$, respectively.

\section{Perceived Stress Items}

Table 2 presents the stress scores for each item according to the academic year of the students and overall scores of five years. The concern about failing the course or year due to the inability to finish clinical school work (clinical score) was the highest stress item (mean score $=3.57$ ). In total, 20 of the $47(43 \%)$ questionnaire items had significant differences $(\mathrm{p}<0.05)$ among the study years of students.

\section{Highest Stress Items in Six Categories by Sex and Academic Year of Students}

Table 3 presents the highest items of six stress categories for males, females and overall scores in the preclinical (first and second years) and clinical years (third, fourth and fifth years). In the academic performance category, the highest stress items were different for males and females in each year, except the fourth year. According to the overall means, in preclinical years, the highest stress items were different for the first and second year. Also, only third-year students showed different highest items than fourth- and fifth-year students in clinical years. In the preclinical and clinical training category, the highest stress items were different in clinical years for the fourth and fifth years with respect to sex. In the patient treatment category, the highest stress item was "patients being late or breaking their appointments" (Item 17) in all the clinical years. In the faculty administration and education staff (professors, instructors or clinical supervisors) category, the highest stress item was different for males and females in the second year. The fourth year showed a different highest stress item than that observed in third- and fifth-year students. In the personal life issues category, the "lack of time for relaxation or leisure activities" (Item 32) was the highest stress item for all preclinical and clinical years. In the professional identity after graduation category, the highest stress item was the "fear of not having the possibility to pursue a postgraduate programme" (Item 46) for all preclinical and clinical years with respect to sex and overall means.

Table 1. Sample distribution by year of students and sex

\begin{tabular}{|c|c|c|c|c|c|c|c|}
\hline Year of study & Total & $\begin{array}{l}\text { Total } \\
\text { Males }\end{array}$ & Females & $\mathrm{N}$ & $\begin{array}{l}\text { Gender } \\
\text { Males }\end{array}$ & Females & Response rate (\%) \\
\hline First year & 446 & 198 & 248 & 278 & 102 & 176 & 62.3 \\
\hline Third year & 406 & 157 & 249 & 259 & 113 & 146 & 63.8 \\
\hline Fourth year & 373 & 159 & 214 & 262 & 110 & 152 & 70.2 \\
\hline Total & 2,045 & 873 & 1,172 & 1,294 & 529 & 765 & 63.3 \\
\hline
\end{tabular}


Table 2. Distribution of mean stress scores, standard deviation and overall means by the year of students and significance among years

\begin{tabular}{|c|c|c|c|c|c|c|c|c|}
\hline & $\begin{array}{l}\text { Question } \\
\text { no }\end{array}$ & First year & $\begin{array}{l}\text { Second } \\
\text { year }\end{array}$ & Third year & $\begin{array}{l}\text { Fourth } \\
\text { year }\end{array}$ & Fifth year & Overall & Significance \\
\hline \multicolumn{9}{|l|}{ Academic performance } \\
\hline Amount of assigned coursework & 1 & $3.28 \pm 0.79$ & $3.55 \pm 0.73$ & $3.48 \pm 0.78$ & $3.48 \pm 0.74$ & $3.25 \pm 0.86$ & $3.42 \pm 0.78$ & $<0.001^{\mathrm{a}, \mathrm{b}, \mathrm{c}, \mathrm{g}, \mathrm{i}, \mathrm{j} j}$ \\
\hline Difficulty of assigned coursework & 2 & $3.37 \pm 0.73$ & $3.51 \pm 0.67$ & $3.41 \pm 0.76$ & $3.36 \pm 0.75$ & $3.25 \pm 0.79$ & $3.39 \pm 0.74$ & $0.003^{9}$ \\
\hline Examinations and grades & 3 & $3.41 \pm 0.72$ & $3.49 \pm 0.74$ & $3.33 \pm 0.78$ & $3.37 \pm 0.72$ & $3.25 \pm 0.80$ & $3.38 \pm 0.75$ & $0.007^{9}$ \\
\hline Competition with classmates & 4 & $1.84 \pm 0.94$ & $2.15 \pm 1.04$ & $2.24 \pm 1.09$ & $2.06 \pm 1.04$ & $2.07 \pm 1.00$ & $2.07 \pm 1.03$ & $<0.001^{\mathrm{a}, \mathrm{b}}$ \\
\hline $\begin{array}{l}\text { Lack of confidence to be a successful } \\
\text { dental student }\end{array}$ & 5 & $2.37 \pm 1.00$ & $2.44 \pm 0.97$ & $2.53 \pm 1.03$ & $2.27 \pm 1.02$ & $2.18 \pm 0.98$ & $2.37 \pm 1.00$ & $0.002^{g, h, i}$ \\
\hline $\begin{array}{l}\text { Fear of failing course, year or a } \\
\text { licensing exam and behaviour of } \\
\text { parents in case of failure }\end{array}$ & 6 & $2.09 \pm 1.02$ & $2.14 \pm 1.08$ & $2.41 \pm 1.12$ & $2.27 \pm 1.09$ & $2.10 \pm 1.07$ & $2.20 \pm 1.08$ & $0.003^{b, e, i}$ \\
\hline $\begin{array}{l}\text { Lack of time to do assigned } \\
\text { laboratory, preclinical or clinical } \\
\text { school work }\end{array}$ & 7 & $3.06 \pm 0.94$ & $3.23 \pm 0.90$ & $3.58 \pm 0.73$ & $3.63 \pm 0.66$ & $3.26 \pm 0.85$ & $3.35 \pm 0.86$ & $<0,001^{b, c, e, f, i, j}$ \\
\hline \multicolumn{9}{|l|}{ Preclinical and clinical training } \\
\hline $\begin{array}{l}\text { Difficulty in learning precision manual } \\
\text { skills required for clinical, preclinical } \\
\text { and laboratory work }\end{array}$ & 8 & $3.07 \pm 0.97$ & $2.93 \pm 0.91$ & $2.98 \pm 0.97$ & $2.82 \pm 0.98$ & $2.9 \pm 0.99$ & $2.95 \pm 0.96$ & $0.047^{c}$ \\
\hline $\begin{array}{l}\text { Responsibilities for comprehensive } \\
\text { patient care and treatment }\end{array}$ & 9 & - & - & $3.07 \pm 0.84$ & $3.07 \pm 0.85$ & $3.04 \pm 0.89$ & $3.06 \pm 0.86$ & 0.898 \\
\hline $\begin{array}{l}\text { Difficulty in learning clinical } \\
\text { procedures and protocols }\end{array}$ & 10 & - & - & $2.90 \pm 0.91$ & $2.80 \pm 0.86$ & $2.79 \pm 0.94$ & $2.83 \pm 0.90$ & 0.358 \\
\hline $\begin{array}{l}\text { Transition to the preclinic to clinic and } \\
\text { facing patient treatment }\end{array}$ & 11 & - & - & $3.01 \pm 0.91$ & $2.85 \pm 0.90$ & $2.91 \pm 0.99$ & $2.92 \pm 0.93$ & 0.152 \\
\hline $\begin{array}{l}\text { Fear of failing course or year because } \\
\text { of the inability to finish clinical school } \\
\text { work (clinical credit) }\end{array}$ & 12 & - & - & $3.69 \pm 0.67$ & $3.57 \pm 0.70$ & $3.42 \pm 0.87$ & $3.57 \pm 0.75$ & $<0.001^{i, j}$ \\
\hline $\begin{array}{l}\text { Lack of confidence in own decision } \\
\text { making during clinical school work }\end{array}$ & 13 & - & - & $2.73 \pm 0.96$ & $2.60 \pm 0.96$ & $2.53 \pm 0.89$ & $2.63 \pm 0.95$ & 0.069 \\
\hline $\begin{array}{l}\text { Fear of unable to catch up if getting } \\
\text { behind the clinical work or course }\end{array}$ & 14 & - & - & $3.19 \pm 0.85$ & $3.18 \pm 0.83$ & $3.14 \pm 0.94$ & $3.18 \pm 0.87$ & 0.839 \\
\hline $\begin{array}{l}\text { Lack of adequate or sufficient number } \\
\text { of patients for clinical exams or clinical } \\
\text { work }\end{array}$ & 15 & - & - & $3.45 \pm 0.78$ & $3.31 \pm 0.85$ & $3.20 \pm 0.92$ & $3.33 \pm 0.85$ & $0.008^{i}$ \\
\hline $\begin{array}{l}\text { Cooperation with dental laboratory } \\
\text { due to timing or faulty working }\end{array}$ & 16 & - & - & $3.43 \pm 0.74$ & $3.59 \pm 0.74$ & $3.48 \pm 0.77$ & $3.50 \pm 0.75$ & 0.052 \\
\hline \multicolumn{9}{|l|}{ Patient treatment } \\
\hline $\begin{array}{l}\text { Patients being late or breaking their } \\
\text { appointments }\end{array}$ & 17 & - & - & $3.12 \pm 0.83$ & $3.00 \pm 0.83$ & $3.04 \pm 0.92$ & $3.05 \pm 0.86$ & 0.249 \\
\hline $\begin{array}{l}\text { Negative or uncomplimentary } \\
\text { attitudes of patients or patient } \\
\text { management }\end{array}$ & 18 & - & - & $2.61 \pm 0.88$ & $2.60 \pm 0.86$ & $2.66 \pm 0.91$ & $2.62 \pm 0.88$ & 0.742 \\
\hline $\begin{array}{l}\text { Lack of communication or cooperation } \\
\text { with patients }\end{array}$ & 19 & - & - & $2.51 \pm 0.89$ & $2.45 \pm 0.91$ & $2.37 \pm 0.89$ & $2.45 \pm 0.90$ & 0.271 \\
\hline Working on patients with dirty mouths & 20 & - & - & $2.68 \pm 0.94$ & $2.63 \pm 0.91$ & $2.74 \pm 0.92$ & $2.68 \pm 0.93$ & 0.440 \\
\hline \multicolumn{9}{|c|}{ Faculty administration and education staff (professors, instructors or clinical supervisors) } \\
\hline $\begin{array}{l}\text { Atmosphere created by professors or } \\
\text { clinical supervisors }\end{array}$ & 21 & - & - & $3.31 \pm 0.80$ & $3.30 \pm 0.76$ & $3.22 \pm 0.84$ & $3.28 \pm 0.80$ & 0.446 \\
\hline $\begin{array}{l}\text { Criticisms from professor or clinical } \\
\text { supervisors in front of patients }\end{array}$ & 22 & - & - & $3.41 \pm 0.81$ & $3.28 \pm 0.86$ & $3.31 \pm 0.86$ & $3.33 \pm 0.84$ & 0.206 \\
\hline $\begin{array}{l}\text { Inconsistency of feedback on your } \\
\text { clinical work among different } \\
\text { professor or instructors }\end{array}$ & 23 & - & - & $3.29 \pm 0.79$ & $3.24 \pm 0.78$ & $3.16 \pm 0.88$ & $3.24 \pm 0.82$ & 0.234 \\
\hline
\end{tabular}


Table 2. continued

Inadequate knowledge and/or clinical experience of the instructors in terms of evaluation of your clinical work (inadequate educational aspects of instructors),

Lack of adequate professors, clinical supervisors or instructors in the clinics

Absence of a professor, clinical supervisor or instructor in clinic when assistance is needed

Rules and regulations of the faculty

Attitudes of staff, clinical supervisor or instructor towards female students

Lack of time to do assigned clinical work or shortage of allocated clinical time

Expectation of dental faculty or the difference between reality of faculty and expectations

The faculty facilities/environment are not sufficient for social, cultural and sports activities

\section{Personal life issues}

Lack of time for relaxation or leisure activities

Difficulty in making friends

Relationship between members of the opposite sex

Difficulty of adaptation to faculty environment

Neglect for personal life

Moving away from home or town

Worried about compatibility of dentistry to personality

Difficult home/hostel environment to study, rest or fun

Lack of financial resources for personal life expenses

Forced postponement of marriage, engagement or having children

Having dual role of wife/husband/ mother/father/dental student

Personal physical health problems due to chronic disease, drugs, alcohol, etc.

Working while studying

Professional identity after graduation

Lack of confidence in self to be a successful dentist after graduation

Fear of not having possibility to pursue a post-graduate programme

Fear of unemployment after graduation

\begin{tabular}{|c|c|c|c|c|c|c|c|}
\hline 24 & - & - & $2.76 \pm 0.93$ & $2.66 \pm 0.94$ & $2.79 \pm 0.90$ & $2.73 \pm 0.93$ & 0.306 \\
\hline 25 & - & - & $2.67 \pm 0.98$ & $2.61 \pm 0.099$ & $2.72 \pm 0.94$ & $2.66 \pm 0.97$ & 0.508 \\
\hline 26 & - & - & $3.03 \pm 0.88$ & $3.10 \pm 0.89$ & $3.06 \pm 0.99$ & $3.06 \pm 0.91$ & 0.662 \\
\hline 27 & $2.78 \pm 0.98$ & $3.08 \pm 0.86$ & $3.21 \pm 0.85$ & $3.34 \pm 0.81$ & $3.03 \pm 0.93$ & $3.09 \pm 0.91$ & $<0,001^{a, b, c, d, f_{j}, j}$ \\
\hline 28 & $2.13 \pm 1.13$ & $2.31 \pm 1.06$ & $2.38 \pm 1.08$ & $2.44 \pm 1.09$ & $2.49 \pm 1.03$ & $2.34 \pm 1.09$ & $0.003^{c, d}$ \\
\hline 29 & - & - & $3.26 \pm 0.82$ & $3.23 \pm 0.87$ & $3.05 \pm 0.88$ & $3.19 \pm 0.86$ & $0.022^{i}$ \\
\hline 30 & $2.91 \pm 0.92$ & $3.03 \pm 0.91$ & $3.21 \pm 0.84$ & $3.26 \pm 0.88$ & $3.14 \pm 0.90$ & $3.10 \pm 0.90$ & $<0,001^{b, c, d, f}, f$ \\
\hline 31 & $3.02 \pm 0.98$ & $3.08 \pm 0.95$ & $3.11 \pm 0.97$ & $3.13 \pm 0.99$ & $2.94 \pm 1.04$ & $3.06 \pm 0.98$ & 0.243 \\
\hline 32 & $3.16 \pm 0.89$ & $3.24 \pm 0.91$ & $3.47 \pm 0.79$ & $3.45 \pm 0.80$ & $3.17 \pm 0.85$ & $3.30 \pm 0.86$ & $<0,001^{b, c, e, f, i, j}$ \\
\hline 33 & $1.77 \pm 0.95$ & $1.89 \pm 1.07$ & $1.70 \pm 0.92$ & $1.56 \pm 0.89$ & $1.85 \pm 0.89$ & $1.75 \pm 0.96$ & $<0,001^{f, j}$ \\
\hline 34 & $1.87 \pm 1.02$ & $1.94 \pm 1.08$ & $1.86 \pm 0.99$ & $1.73 \pm 0.95$ & $1.88 \pm 0.94$ & $1.86 \pm 1.00$ & 0.132 \\
\hline 35 & $2.23 \pm 0.98$ & $2.26 \pm 1.04$ & $2.20 \pm 0.99$ & $2.02 \pm 1.01$ & $2.33 \pm 0.97$ & $2.20 \pm 1.00$ & $0.011^{\mathrm{fj}}$ \\
\hline 36 & $2.74 \pm 1.00$ & $2.78 \pm 1.08$ & $2.88 \pm 1.07$ & $2.86 \pm 1.07$ & $2.89 \pm 0.98$ & $2.83 \pm 1.05$ & 0.394 \\
\hline 37 & $2.55 \pm 1.21$ & $2.36 \pm 1.13$ & $2.44 \pm 1.14$ & $2.35 \pm 1.14$ & $2.41 \pm 1.06$ & $2.42 \pm 1.14$ & 0.246 \\
\hline 38 & $2.36 \pm 1.11$ & $2.43 \pm 1.09$ & $2.35 \pm 1.13$ & $2.35 \pm 1.04$ & $2.34 \pm 1.06$ & $2.37 \pm 1.09$ & 0.862 \\
\hline 39 & $2.45 \pm 1.11$ & $2.46 \pm 1.12$ & $2.30 \pm 1.09$ & $2.29 \pm 1.07$ & $2.10 \pm 0.97$ & $2.34 \pm 1.09$ & $0.002^{\mathrm{d}, \mathrm{g}}$ \\
\hline 40 & $2.53 \pm 1.13$ & $2.58 \pm 1.11$ & $2.70 \pm 1.06$ & $2.57 \pm 1.07$ & $2.61 \pm 1.04$ & $2.60 \pm 1.09$ & 0.459 \\
\hline 41 & $1.89 \pm 1.09$ & $2.09 \pm 1.15$ & $2.08 \pm 1.15$ & $2.05 \pm 1.12$ & $2.12 \pm 1.04$ & $2.04 \pm 1.12$ & 0.143 \\
\hline 42 & $1.67 \pm 1.03$ & $2.03 \pm 1.15$ & $1.89 \pm 1.11$ & $1.76 \pm 1.05$ & $1.87 \pm 1.03$ & $1.85 \pm 1.09$ & $<0,001^{a, f}$ \\
\hline 43 & $1.83 \pm 1.06$ & $2.16 \pm 1.13$ & $1.99 \pm 1.06$ & $1.92 \pm 0.99$ & $2.07 \pm 1.11$ & $2.00 \pm 1.07$ & $0.003^{a}$ \\
\hline 44 & $1.95 \pm 1.09$ & $2.16 \pm 1.12$ & $2.10 \pm 1.11$ & $2.05 \pm 1.04$ & $2.18 \pm 1.12$ & $2.08 \pm 1.10$ & 0.112 \\
\hline 45 & $2.47 \pm 0.97$ & $2.37 \pm 1.03$ & $2.42 \pm 1.01$ & $2.37 \pm 1.02$ & $2.48 \pm 0.96$ & $2.42 \pm 1.00$ & 0.590 \\
\hline 46 & $2.80 \pm 0.98$ & $2.79 \pm 0.98$ & $2.92 \pm 0.97$ & $2.92 \pm 0.97$ & $2.97 \pm 0.90$ & $2.87 \pm 0.97$ & 0.134 \\
\hline 47 & $2.25 \pm 1.06$ & $2.25 \pm 1.05$ & $2.29 \pm 1.05$ & $2.23 \pm 1.04$ & $2.30 \pm 1.05$ & $2.26 \pm 1.05$ & 0.926 \\
\hline
\end{tabular}

Lower case letters denote significant difference between year of students: a: 1-2, b: 1-3, c: 1-4, d: 1-5, e: 2-3, f:2-4, g: 2-5, h: 3-4, i: 3-5, j: 4-5 
Table 3. Means and standard deviations for six stress categories with the highest stress item by year of student or preclinical and clinical years

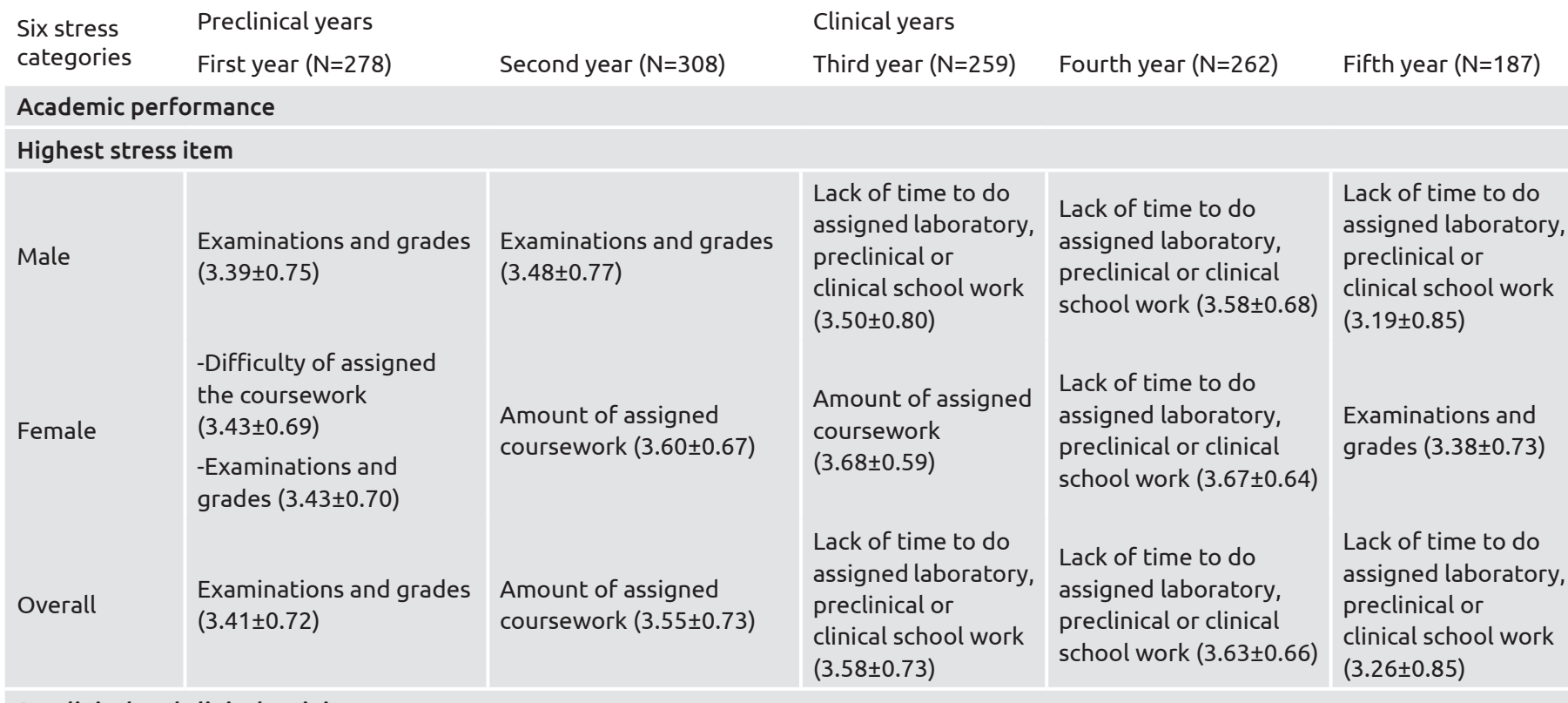

Preclinical and clinical training

Highest stress item

\begin{tabular}{|c|c|c|c|c|c|}
\hline Male & $\begin{array}{l}\text { Difficulty in learning } \\
\text { precision manual skills } \\
\text { required for clinical, } \\
\text { preclinical and laboratory } \\
\text { work }(2.90 \pm 1.00)\end{array}$ & $\begin{array}{l}\text { Difficulty in learning } \\
\text { precision manual skills } \\
\text { required for clinical, } \\
\text { preclinical and laboratory } \\
\text { work }(2.79 \pm 0.89)\end{array}$ & $\begin{array}{l}\text { Fear of failing } \\
\text { course or year } \\
\text { because of the } \\
\text { inability to finish } \\
\text { clinical school work } \\
\text { (clinical score) } \\
(3.52 \pm 0.81)\end{array}$ & $\begin{array}{l}\text { Fear of failing course } \\
\text { or year because } \\
\text { of the inability to } \\
\text { finish clinical school } \\
\text { work (clinical score) } \\
(3.48 \pm 0.71)\end{array}$ & $\begin{array}{l}\text { Cooperation with } \\
\text { dental laboratory } \\
\text { due to timing or } \\
\text { faulty working } \\
(3.37 \pm 0.76)\end{array}$ \\
\hline Female & $\begin{array}{l}\text { Difficulty in learning } \\
\text { precision manual skills } \\
\text { required for clinical, } \\
\text { preclinical and laboratory } \\
\text { work }(3.17 \pm 0.94)\end{array}$ & $\begin{array}{l}\text { Difficulty in learning } \\
\text { precision manual skills } \\
\text { required for clinical, } \\
\text { preclinical and laboratory } \\
\text { work }(3.02 \pm 0.92)\end{array}$ & $\begin{array}{l}\text { Fear of failing } \\
\text { course or year } \\
\text { because of the } \\
\text { inability to finish } \\
\text { clinical school work } \\
\text { (clinical score) } \\
(3.82 \pm 0.51)\end{array}$ & $\begin{array}{l}\text { Cooperation with } \\
\text { dental laboratory due } \\
\text { to timing or faulty } \\
\text { working }(3.72 \pm 0.60)\end{array}$ & $\begin{array}{l}\text { Fear of failing } \\
\text { course or year } \\
\text { because of the } \\
\text { inability to finish } \\
\text { clinical school work } \\
\text { (clinical score) } \\
(3.57 \pm 0.76)\end{array}$ \\
\hline Overall & $\begin{array}{l}\text { Difficulty in learning } \\
\text { precision manual skills } \\
\text { required for clinical, } \\
\text { preclinical and laboratory } \\
\text { work }(3.07 \pm 0.97)\end{array}$ & $\begin{array}{l}\text { Difficulty in learning } \\
\text { precision manual skills } \\
\text { required for clinical, } \\
\text { preclinical and laboratory } \\
\text { work }(2.93 \pm 0.91)\end{array}$ & $\begin{array}{l}\text { Fear of failing } \\
\text { course or year } \\
\text { because of the } \\
\text { inability to finish } \\
\text { clinical school work } \\
\text { (clinical score) } \\
(3.69 \pm 0.67)\end{array}$ & $\begin{array}{l}\text { Cooperation with } \\
\text { dental laboratory due } \\
\text { to timing or faulty } \\
\text { working }(3.59 \pm 0.74)\end{array}$ & $\begin{array}{l}\text { Cooperation with } \\
\text { dental laboratory } \\
\text { due to timing or } \\
\text { faulty working } \\
(3.48 \pm 0.77)\end{array}$ \\
\hline \multicolumn{6}{|c|}{ Patient treatment } \\
\hline \multicolumn{6}{|c|}{ Highest stress item } \\
\hline Male & - & - & $\begin{array}{l}\text { Patients being late } \\
\text { or breaking their } \\
\text { appointments } \\
(2.88 \pm 0.85)\end{array}$ & $\begin{array}{l}\text { Patients being late } \\
\text { or breaking their } \\
\text { appointments } \\
(2.80 \pm 0.83)\end{array}$ & $\begin{array}{l}\text { Patients being late } \\
\text { or breaking their } \\
\text { appointments } \\
(2.87 \pm 0.93)\end{array}$ \\
\hline Female & - & - & $\begin{array}{l}\text { Patients being late } \\
\text { or breaking their } \\
\text { appointments } \\
(3.30 \pm 0.77)\end{array}$ & $\begin{array}{l}\text { Patients being late } \\
\text { or breaking their } \\
\text { appointments } \\
(3.14 \pm 0.80)\end{array}$ & $\begin{array}{l}\text { Patients being late } \\
\text { or breaking their } \\
\text { appointments } \\
(3.17 \pm 0.90)\end{array}$ \\
\hline Overall & - & - & $\begin{array}{l}\text { Patients being late } \\
\text { or breaking their } \\
\text { appointments } \\
(3.12 \pm 0.83)\end{array}$ & $\begin{array}{l}\text { Patients being late } \\
\text { or breaking their } \\
\text { appointments } \\
(3.00 \pm 0.83)\end{array}$ & $\begin{array}{l}\text { Patients being late } \\
\text { or breaking their } \\
\text { appointments } \\
(3.04 \pm 0.92)\end{array}$ \\
\hline
\end{tabular}


Table 2. continued

Faculty administration and education staff (professors, instructors or clinical supervisors)

\section{Highest stress item}

\begin{tabular}{|c|c|c|c|c|c|}
\hline Male & $\begin{array}{l}\text { The faculty facilities/ } \\
\text { environment are not } \\
\text { sufficient for social, } \\
\text { cultural and sports } \\
\text { activities ( } 2.96 \pm 1.05)\end{array}$ & $\begin{array}{l}\text { Rules and regulations of } \\
\text { the faculty }(3.07 \pm 0.88)\end{array}$ & $\begin{array}{l}\text { Criticisms from } \\
\text { professor or clinical } \\
\text { supervisors in } \\
\text { front of patients } \\
(3.30 \pm 0.85)\end{array}$ & $\begin{array}{l}\text { Rules and regulations } \\
\text { of the faculty } \\
(3.17 \pm 0.90)\end{array}$ & $\begin{array}{l}\text { Criticisms from } \\
\text { professor or clinical } \\
\text { supervisors in } \\
\text { front of patients } \\
(3.24 \pm 0.86)\end{array}$ \\
\hline Female & $\begin{array}{l}\text { The faculty facilities/ } \\
\text { environment are not } \\
\text { sufficient for social, } \\
\text { cultural and sports } \\
\text { activities ( } 3.05 \pm 0.93 \text { ) }\end{array}$ & $\begin{array}{l}\text { - Expectation of dental } \\
\text { faculty or the difference } \\
\text { between reality of } \\
\text { faculty and expectations } \\
(3.10 \pm 0.89) \\
\text { - The faculty facilities/ } \\
\text { environment are not } \\
\text { sufficient for social, } \\
\text { cultural and sports } \\
\text { activities ( } 3.10 \pm 0.96)\end{array}$ & $\begin{array}{l}\text { Criticisms from } \\
\text { professor or clinical } \\
\text { supervisors in } \\
\text { front of patients } \\
(3.49 \pm 0.76)\end{array}$ & $\begin{array}{l}\text { Rules and regulations } \\
\text { of the faculty } \\
(3.45 \pm 0.73)\end{array}$ & $\begin{array}{l}\text { Criticisms from } \\
\text { professor or clinical } \\
\text { supervisors in } \\
\text { front of patients } \\
(3.37 \pm 0.85)\end{array}$ \\
\hline \multicolumn{6}{|c|}{ Personal life issues } \\
\hline \multicolumn{6}{|c|}{ Highest stress item } \\
\hline Male & $\begin{array}{l}\text { Lack of time for } \\
\text { relaxation or leisure } \\
\text { activities }(3.02 \pm 0.97)\end{array}$ & $\begin{array}{l}\text { Lack of time for relaxation } \\
\text { or leisure activities } \\
(3.23 \pm 0.92)\end{array}$ & $\begin{array}{l}\text { Lack of time for } \\
\text { relaxation or } \\
\text { leisure activities } \\
(3.29 \pm 0.89)\end{array}$ & $\begin{array}{l}\text { Lack of time for } \\
\text { relaxation or leisure } \\
\text { activities ( } 3.36 \pm 0.84 \text { ) }\end{array}$ & $\begin{array}{l}\text { Lack of time for } \\
\text { relaxation or leisure } \\
\text { activities (3.02 } \pm 0.86)\end{array}$ \\
\hline Female & $\begin{array}{l}\text { Lack of time for } \\
\text { relaxation or leisure } \\
\text { activities }(3.24 \pm 0.83 \text { ) }\end{array}$ & $\begin{array}{l}\text { Lack of time for relaxation } \\
\text { or leisure activities } \\
(3.25 \pm 0.91)\end{array}$ & $\begin{array}{l}\text { Lack of time for } \\
\text { relaxation or } \\
\text { leisure activities } \\
(3.60 \pm 0.67)\end{array}$ & $\begin{array}{l}\text { Lack of time for } \\
\text { relaxation or leisure } \\
\text { activities }(3.51 \pm 0.77)\end{array}$ & $\begin{array}{l}\text { Lack of time for } \\
\text { relaxation or leisure } \\
\text { activities }(3.28 \pm 0.83)\end{array}$ \\
\hline \multicolumn{6}{|c|}{ Professional identity after graduation } \\
\hline \multicolumn{6}{|c|}{ Highest stress item } \\
\hline Male & $\begin{array}{l}\text { Fear of not having } \\
\text { possibility to pursue } \\
\text { a post-graduate } \\
\text { programme }(2.70 \pm 1.01)\end{array}$ & $\begin{array}{l}\text { Fear of not having } \\
\text { possibility to pursue a } \\
\text { post-graduate programme } \\
(2.70 \pm 1.01)\end{array}$ & $\begin{array}{l}\text { Fear of not having } \\
\text { possibility to pursue } \\
\text { a post-graduate } \\
\text { programme } \\
(2.86 \pm 0.93)\end{array}$ & $\begin{array}{l}\text { Fear of not having } \\
\text { possibility to pursue } \\
\text { a post-graduate } \\
\text { programme }(2.74 \pm 1.03)\end{array}$ & $\begin{array}{l}\text { Fear of not having } \\
\text { possibility to pursue } \\
\text { a post-graduate } \\
\text { programme } \\
(2.80 \pm 0.91)\end{array}$ \\
\hline Female & $\begin{array}{l}\text { Fear of not having } \\
\text { possibility to pursue } \\
\text { a post-graduate } \\
\text { programme }(2.86 \pm 0.96)\end{array}$ & $\begin{array}{l}\text { Fear of not having } \\
\text { possibility to pursue a } \\
\text { post-graduate programme } \\
(2.84 \pm 0.96)\end{array}$ & $\begin{array}{l}\text { Fear of not having } \\
\text { possibility to pursue } \\
\text { a post-graduate } \\
\text { programme } \\
(2.96 \pm 1.00)\end{array}$ & $\begin{array}{l}\text { Fear of not having } \\
\text { possibility to pursue } \\
\text { a post-graduate } \\
\text { programme }(3.05 \pm 0.90)\end{array}$ & $\begin{array}{l}\text { Fear of not having } \\
\text { possibility to pursue } \\
\text { a post-graduate } \\
\text { programme } \\
(3.12 \pm 0.86)\end{array}$ \\
\hline Overall & $\begin{array}{l}\text { Fear of not having } \\
\text { possibility to pursue } \\
\text { a post-graduate } \\
\text { programme }(2.80 \pm 0.98)\end{array}$ & $\begin{array}{l}\text { Fear of not having } \\
\text { possibility to pursue a } \\
\text { post-graduate programme } \\
(2.79 \pm 0.98)\end{array}$ & $\begin{array}{l}\text { Fear of not having } \\
\text { possibility to pursue } \\
\text { a post-graduate } \\
\text { programme } \\
(2.92 \pm 0.97)\end{array}$ & $\begin{array}{l}\text { Fear of not having } \\
\text { possibility to pursue } \\
\text { a post-graduate } \\
\text { programme }(2.92 \pm 0.97)\end{array}$ & $\begin{array}{l}\text { Fear of not having } \\
\text { possibility to pursue } \\
\text { a post-graduate } \\
\text { programme } \\
(2.97 \pm 0.90)\end{array}$ \\
\hline
\end{tabular}




\section{Six Stress Categories with Respect to Sex, Year, Overall Scores by Year and Overall Scores of All Five Years}

Table 4 shows the means and standard deviations for the six stress categories with respect to sex, year, overall scores by academic year of students and the overall scores of all five years. The preclinical and clinical training category showed the highest stress mean score (3.09) as compared with the other categories. Except for the categories of patient treatment and professional identity after graduation, there were significant differences among the study years with respect to males or females and the overall means in each stress category. There was a significant difference between males and females with respect to the year of students, except in first and second academic years in academic performance, faculty administration and education staff and personal life issues categories, as well as third and fifth years in the personal life issues category. With regard to the overall mean of males and females of all five years, a significant difference was observed between the sexes in each category. Also, a significant difference was determined among the six categories for the overall means of all five years.

\section{Six Stress Categories by Faculty}

Table 5 shows the means and standard deviations of the six stress categories for each dental faculty.

A significant difference was found among at least two or more faculties for each category. Also, the DF2 displayed higher mean stress values than the other faculties.

\section{Discussion}

Evidence from a systematic review including 124 studies demonstrated that dental students were exposed to a significant amount of stress while training, which was chiefly attributed to the challenging characteristics of the training. Previous studies have indicated the negative effects of increased stress on students' health and well-being (2). Therefore, our aim was to determine the perceived sources and levels of stress in a large population of Turkish dental students across three dental faculties. Also, we aimed to examine the differences in stress sources and levels among faculties to investigate the impact of specific curricular, teaching and institutional differences.

In this study, the overall mean stress scores were considered and the highest stress item changed according to the year of the students. "Examinations and grades" for were highest stress items in the first year, and the "amount of assigned coursework" was the highest stress items in the second year. This was followed by the "difficulty of assigned the coursework" for the first and second years. The first year was mainly dedicated to medical courses and some manual skills and preclinical courses related to prosthetics. Preclinical training and theoretical dental classes are usually taken in the second year. Therefore, the academic environment and dental faculty curriculum are new for first-year students $(6,23,24)$. Silverstein and Kritz-Silverstein (24) found that the DES scores related to class work were high at baseline and increased after one year. Their summations were stress levels resulting from the realisation of the new environment, significant life changes and pressures and anticipation of stressors still to come. In contrast to our results, stress due to academic factors was lower in the second year than in the first year (22). This result might be attributed to the rapid shift in curriculum and subject, to which the new students had difficulty in adjusting. However, in this study, the mean stress of items related to academic performance increased in the second year. This finding may be related to the increase of preclinical work and theoretical dental courses. In accordance with our results, Polychronopoulou and Divaris (12) showed that students in the third year were most affected by acquiring manual skills in the laboratory and preclinical work. The researchers stated that that these students might be overwhelmed by this demanding period. In terms of curriculum, there is a similarity between the second year in our study and the third year in their study. In addition to this result, in the other studies, "examinations and grades" $(6,11,21,24)$, "no time for holiday or reduced holidays" (25), "amount of assigned work" (6), "fear of failing course/year" $(6,11)$, "fear of facing parents after failure" (23), "financial responsibilities" (24), "inconsistency in feedback on work from different instructors" (24) and "fear of unemployment after graduation" (21) were also reported as the top stress items for the first and second year.

There was a trend of increasing overall mean stress scores related to clinical training, patient treatment and clinical education staff. In line with our findings, it was reported that the mean DES scores had a marked rise in the third year, which is the transition year into clinical training. This rise to moderate stress levels for third-year students suggests that the transition might be challenging for many students (11). Another study with similar findings linked the rise with the additional unfamiliar pressures related to patient care (16). In agreement with our findings, the "fear of failing the course or a year" was found as the top stress item in other study $(6,13)$. Although in line with our findings of the first and second years, another study found examinations and grades were the main stressors for all students (20). However, their mean score (2.86) was much lower than that in our study (3.41).

Elani et al. (8) also found that the chief stressors for all dental students were "examinations and grades" and "workload". In contrast, the "amount of assigned work" (7), "examinations" (7), "treatment grades" (11), "completion of clinical requirements" (21), "lack of time for holiday or reduced holidays" (25) were reported as top stress items for third-year students. In our study, the highest stress item "lack of time to do assigned clinical school work" for fourth-year students may related to increased assigned clinical work (clinical credit). In agreement with our findings, Naidu et al. (11) observed that the "shortage of allocated clinical time" was the highest stress item for fourthyear students. They stated that fourth-year students might be more focused on finishing their clinical requirements. Morse and Dravo (21) observed that fourth-year students were the most stressed about learning clinical procedures because the most advanced techniques were learned and put into practice in this year. Also, in another study performed on Turkish dental 


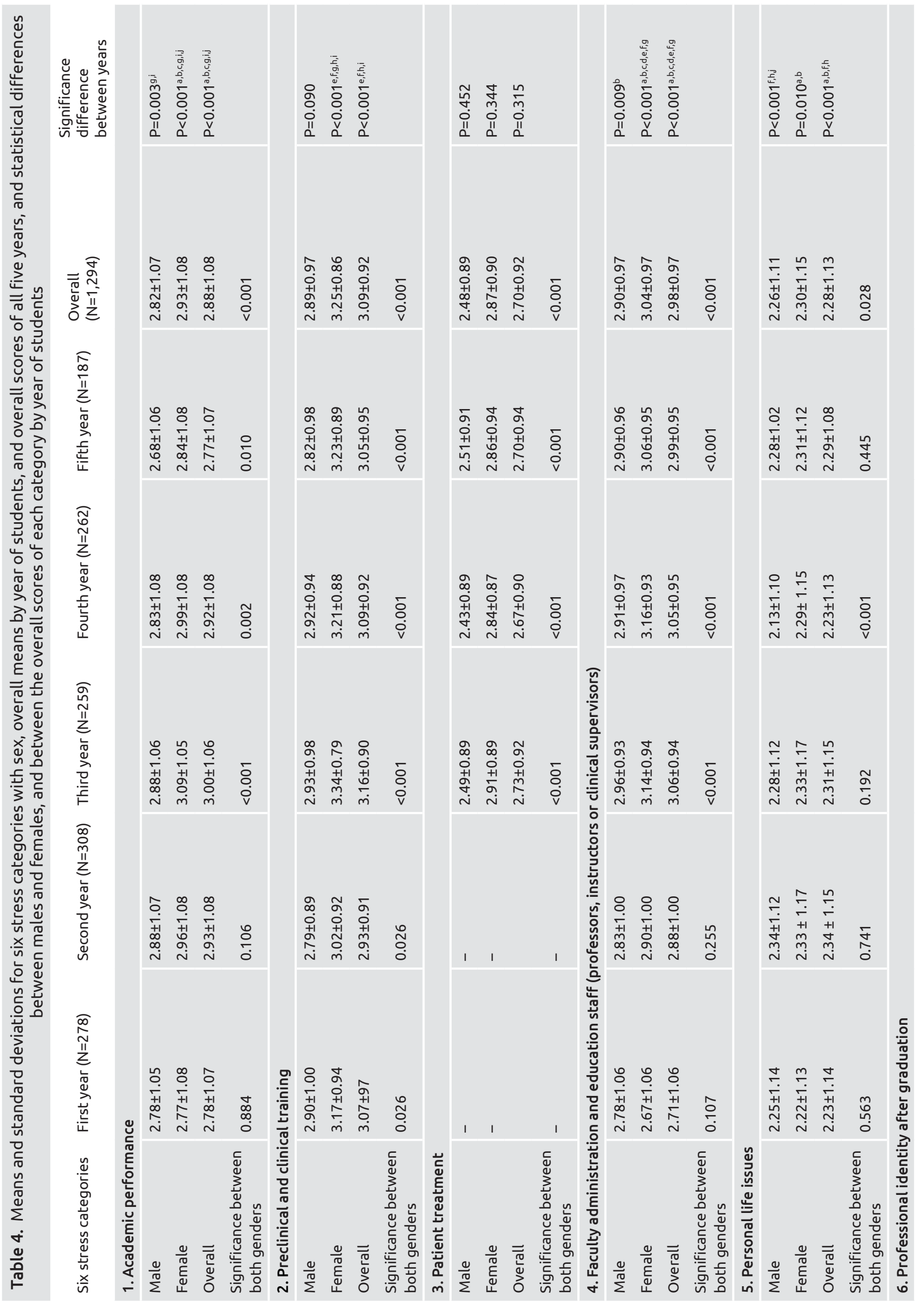




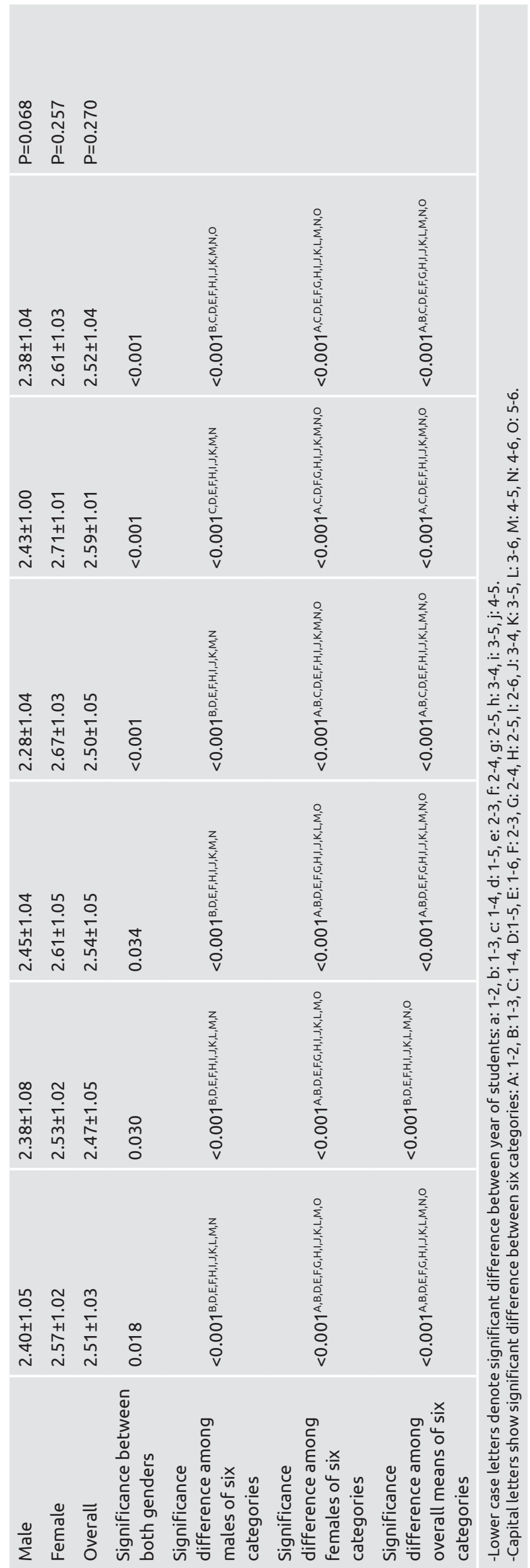

students, the "completion of clinical requirements" and "fear of failing the year" were found as the highest stress items for the fourth year (6). Different to our findings, "examination and grades" (8), "lack of time for relaxation" (12), "lack of time for holiday or reduced holidays" (25) and "financial resources" (21) were reported as the highest stress items. Compared with another study, in our study, the "cooperation with the dental laboratory due to timing or faulty working" was the highest stress item and the overall mean score (3.48) was much higher than their mean scores, which were between 1.73 and $2.53(20,21,25)$. This may be due to the fact that the laboratory workload is excessive and the number of laboratory technicians is insufficient because the students send the prosthetics work to the laboratory to complete their prosthetic credits. In accordance with our findings, it was reported that seniors would naturally be more concerned about the dental laboratory being prompt in the delivery of their cases because they were trying to meet deadlines for completion of graduation requirements (7). In contrast to our findings, "examination and grades" (10), "completion of clinical requirements" (6), "lack of time for holiday or reduced holidays". (25) "fear of failing a course or a year" (11,21), "differences in opinion between clinical staff concerning patient treatment" (20), "fear of facing parents after failure" (23) and "completing clinical requirements" (26) were reported as the highest stress items for fifth- or final-year students.

In our study, there were statistically significant differences among six categories. The preclinical and clinical training category showed the highest mean stress score (3.09). Faculty administration and education staff exhibited the second highest stress mean score (2.98). Difficulties faced in acquiring the precision manual skills needed for preclinical and laboratory work may be the reason for high stress in preclinical years. In clinical years, the transition to the clinic (8), unfamiliar patients care (16) and credit pressure to complete certain numbers and types of clinical cases (8) may be causes of high stress with respect to clinical training. In contrast to our findings, a systematic review reported that for preclinical students, most researchers found that academic factors were the main source of stress (92.5\%). For clinical students, again, most studies identified academic factors as the main cause of stress $(84.0 \%)$, followed by clinical factors $(63.6 \%)$. Faculty and personal issues contributed less to clinical students' stress levels (38.6\% and $11.4 \%$, respectively) (2). However, in accordance with our study, faculty and administration were reported as the highest stress factor in several studies $(1,7,23)$.

In accordance with previous studies, females in our study reported significantly more stress than males in most of the stress items and six stress categories $(4,11,13,16,21)$. One might draw one of a few conclusions: females perceive and experience more stress than males, males are less expressive/private regarding their concerns, or a combination of these or other unknown factors exists (13). It has been reported that that female students might feel more pressure to succeed in a largely male-dominated profession $(11,27)$ and, with that, find the peer pressure and the competitive nature of dental school more stressful $(18,27)$. In contrast to our findings, some studies found that male students 
Table 5. Means and standard deviations of six stress categories for the three dental faculties and a statistical comparison of these three faculties for each category

\begin{tabular}{|c|c|c|c|c|}
\hline Six stress categories & 1. Faculty $(N=554)$ & 2. Faculty $(\mathrm{N}=441)$ & $\begin{array}{l}\text { 3. Faculty } \\
(\mathrm{N}=299)\end{array}$ & $\begin{array}{l}\text { Significance difference } \\
\text { between years }\end{array}$ \\
\hline 1. Academic performance & $2.76 \pm 1.02$ & $3.02 \pm 1.09$ & $2.92 \pm 1.14$ & $<0.001^{a, b, c}$ \\
\hline 2. Preclinical and clinical training & $2.97 \pm 0.90$ & $3.23 \pm 0.91$ & $3.12 \pm 0.97$ & $<0.001^{a, b, c}$ \\
\hline 3. Patient treatment & $2.64 \pm 0.85$ & $2.77 \pm 0.95$ & $2.70 \pm 0.98$ & $0.006^{\mathrm{a}}$ \\
\hline $\begin{array}{l}\text { 4. Faculty administration and education staff } \\
\text { (professors, instructors or clinical supervisors) }\end{array}$ & $2.91 \pm 0.91$ & $3.12 \pm 0.98$ & $2.91 \pm 1.07$ & $<0.001^{a, c}$ \\
\hline 6. Professional identity after graduation & $2.53 \pm 0.99$ & $2.59 \pm 1.07$ & $2.38 \pm 1.06$ & $<0.001^{\mathrm{b}, \mathrm{c}}$ \\
\hline
\end{tabular}

reported higher stress than female students $(20,23)$. Yet in other studies, no difference was found between male and female students $(3,26)$.

In our study, a significant difference was observed in academic performance and preclinical and clinical training stress categories among the three faculties. Also, a significant difference was found among at least two faculties in other stress categories. Students of the second faculty showed a higher stress than other faculties. This difference may be related to the teaching and curriculum issues of each faculty or external factors such as the socioeconomic or sociocultural environment of the cities in which the faculties were located. It is noteworthy that issues raised by the students regarding their courses pertained to different aspects of the curriculum in each school. There is some evidence showing the limited effects of the external environment on stress in dental students; hence, variations of student stress arise from both course-related factors and their immediate surroundings $(3,5)$.

\section{Study Limitation}

This research is limited to three faculties in Turkey's three largest cities. It is not known whether the sources of stress found in the research reflect the local attitudes or are more common. Therefore, the effects of main stressors, especially the curriculum and personal life issues, should be evaluated by conducting studies in more faculties and cities.

\section{Conclusion}

The "fear of failing course or year because of the inability to finish clinical school work" was found as the highest stress item (mean score $=3.57$ ) for all students in five years. However, the highest stress item changed according to the year of the students. "Examinations and grades" for the first year and "amount of assigned coursework" for the second year were found to be the highest stress items. For the third year, the "fear of failing the course or year because of the inability to finish clinical school work"; for the fourth year, the "lack of time to do assigned laboratory, preclinical or clinical school work"; and for the fifth year, the "cooperation with dental laboratory due to timing or faulty working" were the highest stress items. With respect to the six categories, the preclinical and clinical training category was the main source of stress as perceived by all the students. For most of the stress items and six stress categories, females showed significantly more stress than males. In addition, there was a significant difference in the perceived stress levels among at least two or more faculties in each stress category. Curricula need to be rearranged or modified by considering factors that cause stress. Additionally, establishing a student counselling section, assigning student advisors and student-oriented programme planning may reduce the stress caused by dental education. However, further studies are warranted to examine the success of programmes and curricula that reduce stress.

\section{Ethics}

Ethics Committee Approval: Istanbul University Faculty of Dentistry Clinical Research Ethics Committee approved the study protocol. (Protocol Number: 2015/2)

Informed Consent: Informed verbal consent was provided by each volunteer, and they did not receive any compensation for participation in this study.

Peer-review: Externally peer reviewed.

\section{Authorship Contributions}

Concept: M.D., S.T., Design: M.D., N.T., N.Ç., S.T., Data Collection or Processing: N.T., N.Ç., O.Ü., S.Ş., C.B., Analysis or Interpretation: M.D., C.B., Literature Search: M.D., S.T., Writing: M.D., S.T.

Conflict of Interest: No conflict of interest was declared by the authors.

Financial Disclosure: The authors declared that this study received no financial support.

\section{References}

1. Sanders AE, Lushington K. Effect of perceived stress on student performance in dental school. J Dent Educ 2002;66:75-81.

2. Elani HW, Allison PJ, Kumar RA, Mancini L, Lambrou A, Bedos C. A systematic review of stress in dental students. J Dent Educ 2014;78:226-42. 
3. Humphris G, Blinkhorn A, Freeman R, Gorter R, Hoad-Reddick G, Murtomaa H, et al. Psychological stress in undergraduate dental students: baseline results from seven European dental schools. Eur J Dent Educ 2002;6:22-9.

4. Polychronopoulou A, Divaris K. Dental students' perceived sources of stress: a multi-country study. J Dent Educ 2009;73:631-9.

5. Yap AU, Bhole S, Teo CS. A cross-cultural comparison of perceived sources of stress in the dental school environment. J Dent Educ 1996;60:459-64.

6. Peker I, Alkurt MT, Usta MG, Turkbay T. The evaluation of perceived sources of stress and stress levels among Turkish dental students. Int Dent J 2009;59:103-11.

7. Garbee WH Jr, Zucker SB, Selby GR. Perceived sources of stress among dental students. J Am Dent Assoc 1980;100:853-7.

8. Elani HW, Bedos C, Allison PJ. Sources of stress in Canadian dental students: a prospective mixed methods study. J Dent Educ 2013;77:1488-97.

9. Gorter R, Freeman R, Hammen S, Murtomaa H, Blinkhorn A, Humphris G. Psychological stress and health in undergraduate dental students: fifth year outcomes compared with first year baseline results from five European dental schools. Eur J Dent Educ. 2008 May;12(2):61-8. 8-Elani HW, Bedos C, Allison PJ. Sources of stress in Canadian dental students: a prospective mixed methods study. J Dent Educ 2013;77:1488-97.

10. Murphy RJ, Gray SA, Sterling G, Reeves K, DuCette J. A comparative study of professional student stress. J Dent Educ 2009;73:328-37.

11. Naidu RS, Adams JS, Simeon D, Persad S. Sources of stress and psychological disturbance among dental students in the West Indies. J Dent Educ 2002;66:1021-30.

12. Polychronopoulou A, Divaris K. Perceived sources of stress among Greek dental students. J Dent Educ 2005;69:687-92.

13. Divaris K, Polychronopoulou A, Villa-Torres L, Mafla AC, Moya GA, González-Martínez F, et al. Extracurricular factors influence perceived stress in a large cohort of Colombian dental students. J Dent Educ 2014;78:213-25.
14. Büyükgöze-Kavas A. Eating attitudes and depression in a Turkish sample. Eur Eat Disord Rev 2007;15:305-10.

15. -Mocan-Aydın G. Western models of counseling and psychotherapy within Turkey: Crossing cultural boundaries. Counseling Psychologist 2000;28:281-98.

16. Sugiura G, Shinada K, Kawaguchi Y. Psychological well-being and perceptions of stress amongst Japanese dental students. Eur J Dent Educ 2005;9:17-25.

17. Fonseca J, Divaris K, Villalba S, Pizarro S, Fernandez M, Codjambassis A, et al. Perceived sources of stress amongst Chilean and Argentinean dental students. Eur J Dent Educ 2013;17:30-8.

18. Westerman GH, Grandy TG, Ocanto RA, Erskine CG. Perceived sources of stress in the dental school environment. J Dent Educ 1993;57:225-31.

19. Divaris K, Polychronopoulou A, Taoufik K, Katsaros C, Eliades T. Stress and burnout in postgraduate dental education. Eur J Dent Educ 2012;16:35-42.

20. Kumar S, Dagli RJ, Mathur A, Jain M, Prabu D, Kulkarni S. Perceived sources of stress amongst Indian dental students. Eur J Dent Educ 2009;13:39-45.

21. Morse Z, Dravo U. Stress levels of dental students at the Fiji School of Medicine. Eur J Dent Educ 2007;11:99-103.

22. Polychronopoulou A, Divaris K. A longitudinal study of Greek dental students' perceived sources of stress. J Dent Educ 2010;74:524-30.

23. Acharya S. Factors affecting stress among Indian dental students. J Dent Educ 2003;67:1140-8.

24. Silverstein ST, Kritz-Silverstein D. A longitudinal study of stress in first-year dental students. J Dent Educ 2010;74:836-48.

25. Uraz A, Tocak YS, Yozgatligil C, Cetiner S, Bal B. Psychological wellbeing, health, and stress sources in Turkish dental students. J Dent Educ 2013;77:1345-55.

26. Sofola OO, Jeboda SO. Nijeryalı dişhekimliği öğrencilerinde algılanan stres kaynakları. Eur J Dent Educ 2006;10:20-3.

27. Heath JR, Macfarlane TV, Umar MS. Perceived sources of stress in dental students. Dent Update 1999;26:94-8, 100. 